Tobacco Company, deals at length with night-riding itself, and outlines the major factors, including legal prosecution, that contributed to the decline of organized terror. Kroll grew up in the tobacco region, taught for many years in the schools and colleges of Kentucky and Tennessee, and came to know firsthand the folkways and folklore of the people he is writing about. He is most successful in his evocation of their way of life and in describing the hazards and hardships of tobacco farming. $\mathrm{He}$ tells his story with wit and compassion, frequently lapsing into the earthy vernacular of the rude folk who lived on the small farms of the Black Patch. Although he has used some local newspapers and most of the available secondary materials, his work is essentially a personal account based on his own observations and intimate familiarity with the legends and traditions of the area. The book is not documented and the author admits that parts of it are "written in fictional form."

Kroll cannot be criticized for failing to produce a book he never intended to write. On the other hand, he adds little to what has already been written on this bizarre episode in recent American history. Twentyfive years ago Theodore Saloutos, in an article on the American Society of Equity in Kentucky, suggested that the farmers' movement in the dark-tobacco belt is a chapter of some importance in the nation's economic and business history. Unfortunately, these aspects of the Black Patch War have not yet been adequately explored, certainly not in Kroll's book. The business affairs of the Planters' Protective Association have yet to be investigated, and such questions as the actual effect of the tobacco "trust" on leaf prices and market conditions and the actual influence of the farmers' organization in the economic and political realms remain unanswered.

\title{
FRIEDRICH HARKORT, Bd. 1: 1793-1838. By Wolfgang Köllmann. Dusseldorf, Droste Verlag, 1964. Pp. 228.
}

Reviewed by Rudolf Braun University of Berne

Two volumes are planned for the biography of Friedrich Harkort (1793-1874); can such an extensive study be justified? After reading the first volume the reviewer does not hesitate to answer yes. On one hand, the legitimation arises from the impact of his personality and work upon his time. Harkort was not only a daimonic, Schumpeterian entrepreneur striving for technical progress and industrial innovations in the fields of steam-engineering, railroads, and shipbuilding, but also an early spokesman for social reforms - both in word and deed, that is a publicist and as a member of the provincial parliament, and later on of the German parliament. On the other hand, such an extensive biography is justified by the author's intention not to limit his line of sight to Harkort himself, but to find a synthesis between the individualistic approach - which is of course inevitable in writing a biography - and a sociostructural analysis of the environment in which Harkort acted: the early industrialization and the formation of an "Industrial Society" in postNapoleonic Germany are connected with and illustrated by Harkort's life. For such an attempt Harkort is an ideal figure and Köllmann - the 
author of the comprehensive book "Sozialgeschichte der Stadt Barmen im 19. Jahrhundert" - well prepared indeed. To show this, we can not do more than give a few indications.

Harkort's descent and his years of adolescence enable Köllmann to outline the socio-economic and cultural background of a milieu which was an important seedbed of entrepreneurs and business leaders during the period of early industrialization in Rhineland-Westphalia: a group of landed merchant-producers, mainly in the field of iron industry. Though they increased their activities in industry and trade during the eighteenth century, these families remained firmly rooted in their estates, continuing to be engaged in farming and to provide leadership in the rural area. Harkort's family belonged to this group.

Harkort's industrial enterprises fall entirely in the time-period covered by the first volume. In the end they failed because Harkort wanted to accomplish too much too quickly. This chapter is a fascinating story of an entrepreneur at work, who had in various fields the foresight of future technical and economic development. Harkort's entrepreneurial activities illustrate two aspects which deserve special mention. While building up his engineering works in Wetter, he went to England to hire engineers and skilled labourers. Most of these men whom he brought over to Germany were some kind of "industrial legionaries," who - in Harkort's own words - "had to be cut loose, so to speak, from the gallows." The second aspect refers to the governmental support Harkort received for his industrial enterprises. Eager to narrow the gap of technical knowhow which existed between England and continental Europe, the Prussian Government provided the potential entrepreneurs with financial and technical assistance (designs of machines or the machines themselves). Köllmann gives a detailed description of Harkort's cooperation with governmental agencies.

The last two chapters of the first volume deal with the beginning of Harkort's career as publicist and politician. Of special interest here are the projects of roads and railroads which he worked out and advocated in local newspapers and in the provincial diet of Westphalia, of which he was a member. His efforts in the field of social reforms will be the subject of the second volume.

Köllmann's well-written book provides rewarding reading and leaves the reader eager to see the second volume.

THE RED KINGDOM OF SAXONY: LOBBYING GROUNDS FOR GUSTAV STRESEMANN, 1901-1909. By Donald Warren, Jr. The Hague, Martinus Nijhoff, Publisher, 1964. Pp. xii +105.11 .75 guilders.

Reviewed by John Snell Tulane University

This small book was developed from the author's Columbia University dissertation (1959) on Stresemann as an organizer of German business interests, 1901-1914. Excellent! - for biographies of this outstanding leader of the Weimar Republic have not been very helpful on this facet of Stresemann's career. Obviously his political objectives and style were 